\title{
Article
}

\section{Tantalum-Doped $\mathrm{TiO}_{2}$ Prepared by Atomic Layer Deposition and Its Application in Perovskite Solar Cells}

\author{
Chia-Hsun Hsu ${ }^{1}$, Ka-Te Chen ${ }^{1}$, Ling-Yan Lin ${ }^{2,3}$, Wan-Yu Wu ${ }^{4}$, Lu-Sheng Liang ${ }^{5}$, Peng Gao ${ }^{5}$, Yu Qiu ${ }^{2,3}$, \\ Xiao-Ying Zhang ${ }^{1}$, Pao-Hsun Huang ${ }^{6}{ }^{(\mathbb{D}}$, Shui-Yang Lien ${ }^{1,4,7, *}$ and Wen-Zhang Zhu ${ }^{1,7}$
}

1 School of Opto-Electronic and Communication Engineering, Xiamen University of Technology, Xiamen 361024, China; chhsu@xmut.edu.cn (C.-H.H.); 1922031007@stu.xmut.edu.cn (K.-T.C.); xyzhang@xmut.edu.cn (X.-Y.Z.); wzzhu@xmut.edu.cn (W.-Z.Z.)

2 Key Laboratory of Green Perovskites Application of Fujian Province Universities, Fujian Jiangxia University, Fuzhou 350108, China; lingyanlin@fjjxu.edu.cn (L.-Y.L.); yuqiu@fjjxu.edu.cn (Y.Q.)

3 College of Electronics and Information Science, Fujian Jiangxia University, Fuzhou 350108, China

4 Department of Materials Science and Engineering, Da-Yeh University, Changhua 51591, Taiwan; wywu@mail.dyu.edu.tw

5 CAS Key Laboratory of Design and Assembly of Functional Nanostructures, Fujian Provincial Key Laboratory of Nanomaterials, Fujian Institute of Research on the Structure of Matter, Chinese Academy of Sciences, Fuzhou 350002, China; lushengliang@fjirsm.ac.cn (L.-S.L.); peng.gao@fjirsm.ac.cn (P.G.)

6 School of Information Engineering, Jimei University, Xiamen 361021, China; ph.huang@jmu.edu.cn

7 Fujian Key Laboratory of Optoelectronic Technology and Devices, Xiamen University of Technology, Xiamen 361024, China

* Correspondence: sylien@xmut.edu.cn

check for updates

Citation: Hsu, C.-H.; Chen, K.-T.; Lin, L.-Y.; Wu, W.-Y.; Liang, L.-S.; Gao, P.; Qiu, Y.; Zhang, X.-Y.; Huang, P.-H.; Lien, S.-Y.; et al. Tantalum-Doped $\mathrm{TiO}_{2}$ Prepared by Atomic Layer Deposition and Its Application in Perovskite Solar Cells. Nanomaterials 2021, 11, 1504. https://doi.org/ 10.3390/nano11061504

Academic Editor: Vlad Andrei Antohe

Received: 30 April 2021

Accepted: 4 June 2021

Published: 7 June 2021

Publisher's Note: MDPI stays neutral with regard to jurisdictional claims in published maps and institutional affiliations.

Copyright: (c) 2021 by the authors. Licensee MDPI, Basel, Switzerland. This article is an open access article distributed under the terms and conditions of the Creative Commons Attribution (CC BY) license (https:// creativecommons.org/licenses/by/ $4.0 /)$.

\begin{abstract}
Tantalum (Ta)-doped titanium oxide $\left(\mathrm{TiO}_{2}\right)$ thin films are grown by plasma enhanced atomic layer deposition (PEALD), and used as both an electron transport layer and hole blocking compact layer of perovskite solar cells. The metal precursors of tantalum ethoxide and titanium isopropoxide are simultaneously injected into the deposition chamber. The Ta content is controlled by the temperature of the metal precursors. The experimental results show that the Ta incorporation introduces oxygen vacancies defects, accompanied by the reduced crystallinity and optical band gap. The PEALD Ta-doped films show a resistivity three orders of magnitude lower than undoped $\mathrm{TiO}_{2}$, even at a low Ta content (0.8-0.95 at.\%). The ultraviolet photoelectron spectroscopy spectra reveal that Ta incorporation leads to a down shift of valance band and conduction positions, and this is helpful for the applications involving band alignment engineering. Finally, the perovskite solar cell with Ta-doped $\mathrm{TiO}_{2}$ electron transport layer demonstrates significantly improved fill factor and conversion efficiency as compared to that with the undoped $\mathrm{TiO}_{2}$ layer.
\end{abstract}

Keywords: tantalum; titanium oxide; atomic layer deposition; bubbler temperature; perovskite solar cell; electron transport layer

\section{Introduction}

Titanium dioxide $\left(\mathrm{TiO}_{2}\right)$ thin films are widely studied owing to their optoelectrical properties that fulfill the requirements of numerous applications such as dye-sensitized photovoltaic devices [1], photocatalysis [2], and perovskite solar cells (PSCs) [3]. In order to enhance properties, the $\mathrm{TiO}_{2}$ films are commonly doped with transition metal, rare metal, or noble metal ions [4-9]. Some studies indicate that the electron-hole recombination could be reduced due to the generation of the charge trapping centers by foreign ions [10]. A moderate amount of metal dopants promotes the excitons separation and thus improves the mobility of photogenerated carriers [11-13]. Due to the wide forbidden energy gap and the absorption only at UV-light region, the $\mathrm{TiO}_{2}$ films are intentionally doped in order to reduce the energy gap and extend the light absorption to visible light in some applications [14]. The reduced band gap results from the generation of oxygen vacancies 
produced simultaneously through doping, introducing shallow energy levels below the conduction band edge $[15,16]$. Zhao et al. reported that doped $\mathrm{TiO}_{2}$ with suitable metal ions can effectively improve the electron transport of $\mathrm{TiO}_{2}$ [17]. Among various dopants, $\mathrm{Ta}^{5+}$ has an ionic radius $(0.64 \AA)$ very close to $\mathrm{Ti}^{4+}(0.61 \AA)$, and thus it is able to be incorporated into the $\mathrm{TiO}_{2}$ lattice without severe strain or secondary phase production [18]. Doping with Ta is also more effective than with niobium, and has lower formation energy consumption and superior thermodynamic stability compared to doping with nitrogen [13]. Ta-doped $\mathrm{TiO}_{2}$ thin films can be prepared by various methods such as sputtering [19], solgel spin-coating [13], and chemical vapor deposition [20]. Recently, due to the demands of slim and thin electronics or the requirements of depositing films on high aspect ratio substrates, atomic layer deposition (ALD) technique receives great attention because of its pinhole-free deposition process, accurate thickness control at sub-nanometer level, and high conformality [21]. The Ta incorporation into $\mathrm{ALD} \mathrm{TiO} 2$ films is mostly carried out by using the $\mathrm{Ta}_{2} \mathrm{O}_{5} / \mathrm{TiO}_{2}$ multilayer structure, and controlled by the ALD cycle ratio of the two metal oxides $[18,22]$.

As for planar perovskite solar cells, the electron transport layer (ETL) plays a crucial role in electron transport and hole blocking. Due to the fact that ETLs are mostly prepared using the sol-gel process, the layer may contain pinholes or have low density, rendering holes possible to pass the ETL to increase the recombination rate. A compact layer is usually inserted at the sol-gel ETL/transparent electrode interface to improve the hole blocking ability. Thanks to the pinhole-free structure and highly conformal coverage, a thin ALD layer is able to be used as both ETL and compact layer for the perovskite solar cells [23]. However, the conduction band edge of $\mathrm{TiO}_{2}($ about $-3.9 \mathrm{eV}$ ) is shallower than that of cesium formamidinium-based $\mathrm{Cs}_{\mathrm{x}} \mathrm{FA}_{1-\mathrm{x}} \mathrm{Pb}\left(\mathrm{I}_{1-\mathrm{y}} \mathrm{Br}_{\mathrm{y}}\right)_{3}$ (about $-4.2 \mathrm{eV}$ ), which is one of the most promising classes of perovskite light absorber for solar cells due to its wide band gap and higher durability compared to $\mathrm{MAPbI}_{3}$ [24]. The conduction band mismatch at the $\mathrm{TiO}_{2} \mathrm{ETL} /$ perovskite interface causes a barrier that is theoretically unfavorable for electron transport. Development of doped $\mathrm{TiO}_{2}$ ETLs is one possible way to have a better band alignment and an improved PSC performance.

In the present study, Ta-doped $\mathrm{TiO}_{2}$ films are grown by using plasma enhanced ALD (PEALD), and used as an ETL for PSCs. The metal precursors tantalum ethoxide $\left(\mathrm{Ta}(\mathrm{OEt})_{5}\right)$ as Ta dopant source and titanium isopropoxide (TTIP) as Ti source are simultaneously fed into the deposition chamber. The precursor output flows are controlled by the bubbler temperature, which is varied from $70-90{ }^{\circ} \mathrm{C}$ to obtain different Ta doping ratio. The effects of the bubbler temperature on the structural, electrical, and optical properties of the Tadoped $\mathrm{TiO}_{2}$ films are investigated. The adjustments of the band gap, conduction band, and valence band positions are presented. Finally, the Ta-doped $\mathrm{TiO}_{2}$ ETL is applied to PSC fabrication, and the improved conversion efficiency and hysteresis is demonstrated and discussed.

\section{Materials and Methods}

\subsection{Thin Film Preparation}

Glass substrates with a size of $20 \mathrm{~mm} \times 20 \mathrm{~mm}$ and a thickness of $1 \mathrm{~mm}$ were cleaned in an ultrasonic bath with deionized water, acetone, and ethanol for $15 \mathrm{~min}$, and then dried in an oven at $70{ }^{\circ} \mathrm{C}$ for $30 \mathrm{~min}$. The substrates were placed on the substrate holder in the deposition chamber of PEALD (R200 advance, Picosun Oy, Espoo, Finland). The used metal precursors were $\mathrm{Ta}(\mathrm{OEt})_{5}$ and TTIP (Aimou Yuan Scientific, Nanjing, China) as the Ta and Ti sources, respectively. Nitrogen with a purity of $99.999 \%$ was introduced to the precursor bubblers to transport the precursor vapors to the deposition chamber. The oxidant was provided by inductively coupled oxygen-argon mixed plasma generated by an RF power of $1500 \mathrm{~W}$. The substrate temperature was $250{ }^{\circ} \mathrm{C}$. The temperatures of the $\mathrm{Ta}(\mathrm{OEt})_{5}$ and TTIP bubblers were controlled from 70 to $90^{\circ} \mathrm{C}$ by means of a heating jacket. The thickness of the Ta-doped $\mathrm{TiO}_{2}$ films was $60 \mathrm{~nm}$. The undoped films were prepared under identical 
conditions, except for the use of the TTIP metal precursor alone. The detailed deposition parameters for the PEALD Ta-doped $\mathrm{TiO}_{2}$ films are summarized in Table 1.

Table 1. Deposition parameters of the PEALD Ta-doped $\mathrm{TiO}_{2}$ films.

\begin{tabular}{cc}
\hline Parameter & Value \\
\hline Substrate temperature $\left({ }^{\circ} \mathrm{C}\right)$ & 250 \\
Bubbler temperature $\left({ }^{\circ} \mathrm{C}\right)$ & $70-90$ \\
Nitrogen carrier flow rate $(\mathrm{sccm})$ & 120 \\
Metal precursor pulse time $(\mathrm{s})$ & 1.6 \\
Metal precursor purge time $(\mathrm{s})$ & 6 \\
$\mathrm{O}_{2}$ flow rate $(\mathrm{sccm})$ & 150 \\
$\mathrm{O}_{2}$ pulse time $(\mathrm{s})$ & 11 \\
$\mathrm{O}_{2}$ purge time $(\mathrm{s})$ & 5 \\
$\mathrm{O}_{2}$ plasma power $(\mathrm{W})$ & 1500 \\
Ar flow rate $(\mathrm{sccm})$ & 80 \\
Post annealing temperature $\left({ }^{\circ} \mathrm{C}\right)$ & 500 \\
\hline
\end{tabular}

\subsection{Perouskite Solar Cell Fabrication}

The $15 \mathrm{~nm}$-thick $\mathrm{ALD} \mathrm{TiO}_{2}$ films were deposited on the cleaned fluorine-doped tin oxide (FTO) substrates. Lead iodide, lead bromide, methylammonium bromide, and formamidinium iodide were dissolved with a molar ratio of 1:1.15:0.2:0.2 in $\mathrm{N}, \mathrm{N}$-dimethylformamide (DMF) and dimethyl sulfoxide (DMSO) with 4:1 volume ratio. The CsI dissolved in DMSO as $1.5 \mathrm{~mol}$ stock solution was further poured to give $\mathrm{Cs}_{0.1}\left(\mathrm{FA}_{0.83} \mathrm{MA}_{0.17}\right)_{0.9} \mathrm{~Pb}\left(\mathrm{I}_{0.83} \mathrm{Br}_{0.17}\right)_{3}$. The perovskite precursor solution was then spin-coated on ALD doped or undoped $\mathrm{TiO}_{2}$ ETL in two steps, the first spreading step with $1000 \mathrm{rpm}$ for $10 \mathrm{~s}$ and the second step with $6000 \mathrm{rpm}$ for $25 \mathrm{~s}$. Chlorobenzene of $110 \mu \mathrm{L}$ was sprayed on the spinning substrate at five seconds before the end of the second-step spin-coating process. Afterwards, an annealing process at $100{ }^{\circ} \mathrm{C}$ was performed for $60 \mathrm{~min}$. Spiro-OMeTAD (Lumtec, New Taipei, Taiwan) of $50 \mathrm{uL}$ was spin-coated on the perovskite with $4000 \mathrm{rpm}$ for $30 \mathrm{~s}$ following cool down of the substrate back to room temperature. Finally, the cell fabrication was finished by evaporating gold films on the Spiro-OMeTAD. The devices had an active area of $0.1 \mathrm{~cm}^{2}$.

\subsection{Characterization}

The thickness of the films was determined using an ellipsometer (M-2000, J. A. Woollan Co., Lincoln, NE, USA). The ultraviolet-visible spectrometer (MFS630, Hong-Ming, New Taipei City, Taiwan) was employed to obtain the transmittance spectra. The X-ray diffraction apparatus (XRD, Rigaku TTRAXIII, Ibaraki, Japan) was used for characterizing the crystalline structure of the films. The X-ray photoelectron spectroscopy (XPS, ESCALAB 250Xi, Thermo Fisher, Waltham, MA, USA) was used in order to investigate the chemical states and elemental composition of the films. The Fermi-level and valance band position of the Ta-doped $\mathrm{TiO}_{2}$ films were obtained using UV photoelectron spectroscopy (UPS, ESCALAB Xi ${ }^{+}$, Thermo Fisher Scientific, Gloucester, UK) with He I source (photon energy of $21.2 \mathrm{eV}$ ). The resistivity of the films was examined by using a four-point probe (T2001A3, Ossila, Sheffield, UK). The current density-voltage (J-V) curves and solar cell external parameters such as open-circuit voltage $\left(\mathrm{V}_{\mathrm{oc}}\right)$, short-circuit current density $\left(\mathrm{J}_{\mathrm{sc}}\right)$, fill factor $(F F)$, and conversion efficiency $(\eta)$ were measured at AM1.5G $\left(100 \mathrm{~mW} / \mathrm{cm}^{2}\right)$ using a solar simulator (Newport Oriel, Irvine, CA, USA).

\section{Results and Discussion}

In this work, $\mathrm{Ta}(\mathrm{OEt})_{5}$ precursor is used as the Ta dopant source, and co-injected with TTIP precursor into the deposition zone. The amount of the output precursor molecules is determined by the bubbler temperature controlling the vapor pressure of the metal 
precursors. Figure 1a shows the temperature-dependent vapor pressures of TTIP and $\mathrm{Ta}(\mathrm{OEt})_{5}$ as given by:

$$
\begin{gathered}
P_{\mathrm{Ta}(\mathrm{OEt}) 5}=10^{9.66-\frac{4288}{T},} \\
P_{\text {TTIP }}=10^{10.12-\frac{3425}{T}},
\end{gathered}
$$

where $P$ is the vapor pressure (unit in $\mathrm{mmHg}$ ), and $T$ is the bubbler temperature. Both of the metal vapor pressures increase with the bubbler temperature. It is believed that the film growth is related to the output vapors of metal precursors, which can be controlled by either varying the carrier gas flows or the bubbler temperature. The latter is adopted in this study. Figure $1 \mathrm{~b}$ shows the deposition rates of the PEALD Ta-doped $\mathrm{TiO}_{2}$ films prepared at different bubbler temperatures. The value of the undoped film is also indicated for comparison. It is seen that the $\mathrm{TiO}_{2}$ has a deposition rate of $0.252 \AA$ /cycle, which is similar to that reported by other groups $[25,26]$. The deposition rate is not much affected at the bubbler temperature of $70^{\circ} \mathrm{C}$, and then increases from 0.252 to $0.284 \AA$ / cycle when the bubbler temperature increases from 70 to $90^{\circ} \mathrm{C}$. It is reported that the deposition rate of the ALD tantalum oxide is $0.5-1 \AA$ /cycle $[27,28]$, which is nearly two to four times higher than that of $\mathrm{TiO}_{2}$. This may be one explanation for the increased deposition rate for the Ta-doped $\mathrm{TiO}_{2}$. Another reason is that Ta incorporation leads to a less dense film structure due to the donor doping induced oxygen vacancies defects to maintain charge neutral as commonly seen in doped metal oxides [16]. The relatively loose film structure of the Ta-doped $\mathrm{TiO}_{2}$ contributes to a higher film thickness.

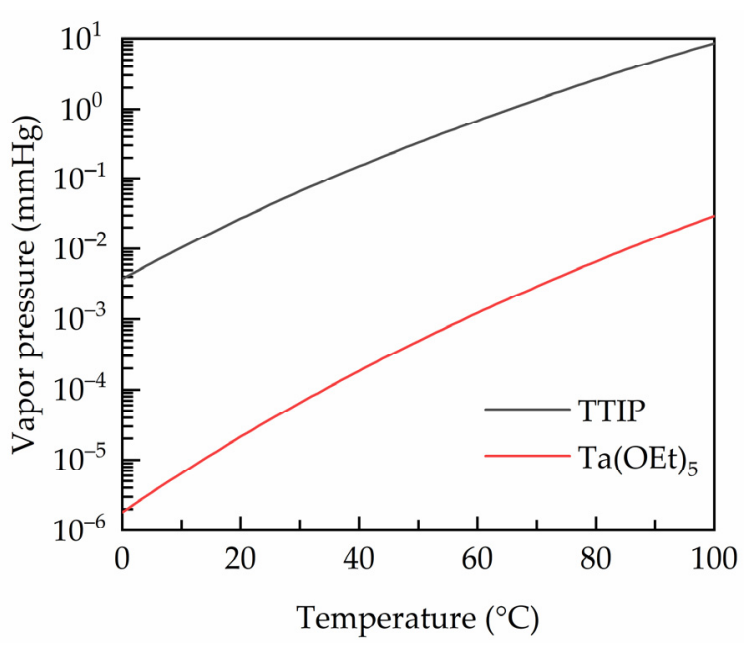

(a)

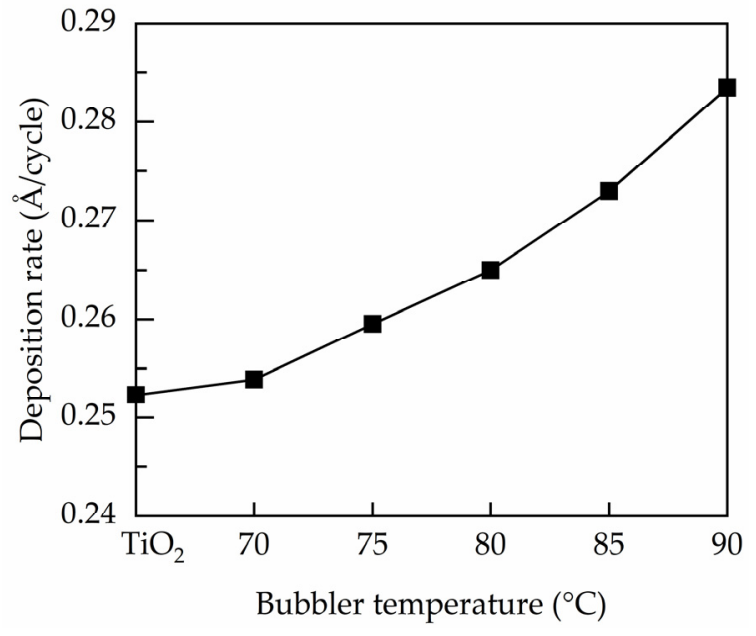

(b)

Figure 1. (a) Temperature-dependent vapor pressures of the TTIP and Ta(OEt $)_{5}$ metal precursors. (b) Deposition rate of the PEALD films prepared at various bubbler temperatures.

Figure 2a shows the transmittance over a wavelength range from 300 to $800 \mathrm{~nm}$ for the PEALD films prepared at various bubbler temperatures. The lower transmittance at the short wavelength region is related to the band-to-band absorption of the $\mathrm{TiO}_{2}$ films. The transmittance decreases with increasing the bubbler temperature, indicating that the increase of Ta concentration enhances the absorption. The reduced transmittance could also be a consequence of the light scattering caused by the oxygen vacancies [29]. The inset shows the transmittance in the short-wavelength region $(300-400 \mathrm{~nm})$ to evaluate the absorption edge. It can be seen that the edge shifts towards longer wavelength direction when the bubbler temperature increases, inferring the reduced band gap. Figure $2 b$ shows the band gap deduced from Tauc's equation [30]:

$$
(\alpha \mathrm{hv})^{\mathrm{n}}=\mathrm{A}\left(\mathrm{hv}-\mathrm{Eg}_{\mathrm{g}}\right)
$$


where $\alpha$ is the absorption coefficient, hv is the photon energy, A is the material-dependent constant, and $\mathrm{E}_{\mathrm{g}}$ is the band gap. The $\mathrm{n}$ value is taken as $1 / 2$ for indirect band gap anatase $\mathrm{TiO}_{2}$ [31]. The band gap values of the PEALD films are evaluated by plotting $(\alpha \mathrm{hv})^{1 / 2}$ versus hv and extrapolating the linear region of the resultant curves to obtain an interception with the hv-axis. The band gap of the $\mathrm{TiO}_{2}$ is $3.17 \mathrm{eV}$, and it decreases from 3.09 to $3 \mathrm{eV}$ by increasing the bubbler temperature from 70 to $90{ }^{\circ} \mathrm{C}$. This is possibly related to the band gap narrowing effect due to the formation of the oxygen vacancies defects that introduce shallow donor levels below the conduction band. Similar effect can also be observed elsewhere [32].

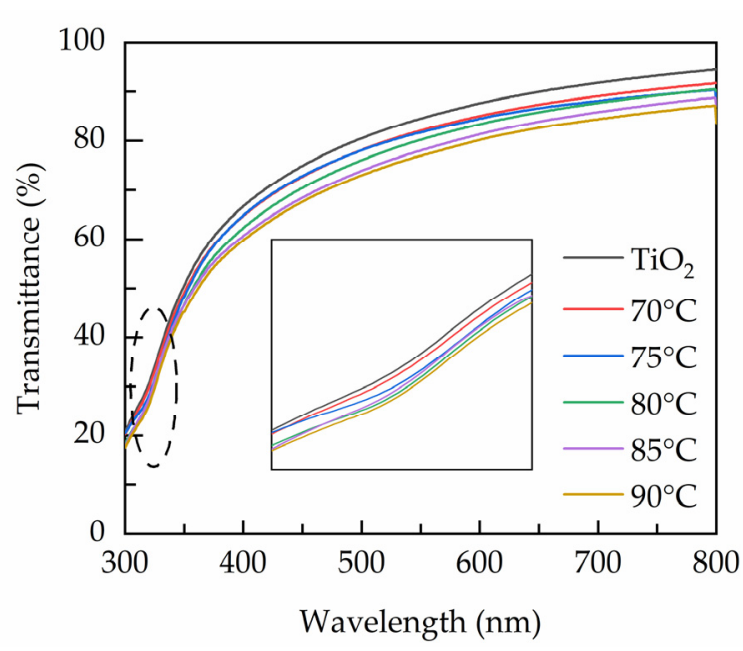

(a)

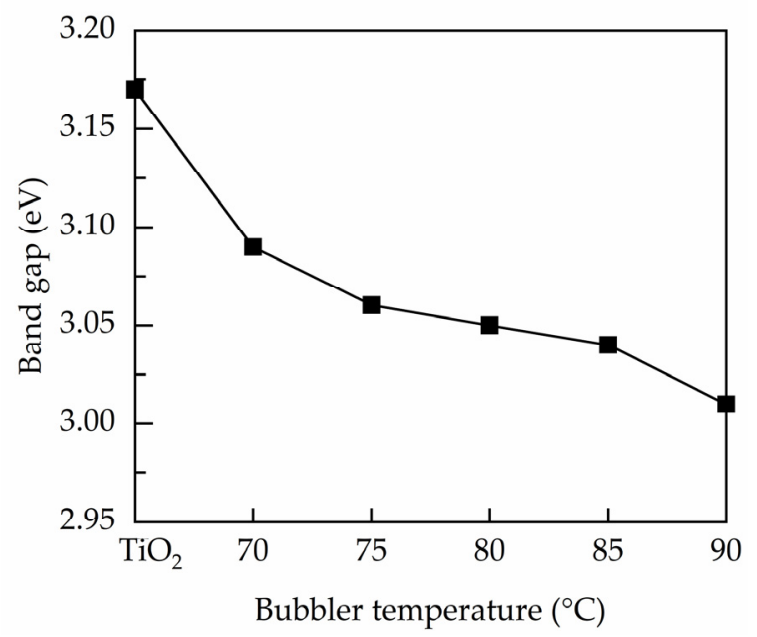

(b)

Figure 2. (a) Transmittance spectra and (b) band gap of the PEALD films prepared with various bubbler temperatures.

Figure 3a shows the XRD patterns of the PEALD undoped and Ta-doped $\mathrm{TiO}_{2}$ films. The peaks labeled are well matched to anatase $\mathrm{TiO}_{2}$ (JCPSD\#83-2243). With Ta doping, the (103), (004), and (112) peaks vanish, but no additional peak such as Ta or $\mathrm{Ta}_{2} \mathrm{O}_{5}$ is found, indicating that $\mathrm{Ta}$ atoms are well-incorporated into the $\mathrm{TiO}_{2}$ crystalline structure by replacing $\mathrm{Ti}^{4+}$ at random lattice sites. The full width at half maximum (FWHM) of the most intense (101) orientation is extracted to calculate crystallite size according to the Scherrer equation:

$$
L=\frac{K \lambda}{\beta \cos \theta}
$$

with $L$ the crystallite size, $K$ the shape factor taken as $0.9, \lambda$ the $X$-ray wavelength $(0.154 \mathrm{~nm})$, $\beta$ is the width of the observed diffraction line at its half intensity maximum, and $\theta$ is the Bragg angle. Figure 3b illustrates the FWHM and crystallite size as function of bubbler temperature. It is seen that the FWHM increases when $\mathrm{Ta}$ is substituted into $\mathrm{TiO}_{2}$, suggesting that the crystallinity is diminished. The crystallite size reduces from $28 \mathrm{~nm}$ for undoped $\mathrm{TiO}_{2}$ to $23 \mathrm{~nm}$ for the film deposited at the bubbler temperature of $70{ }^{\circ} \mathrm{C}$. Further increasing the bubbler temperature up to $90^{\circ} \mathrm{C}$ results in a slight reduction in crystallite size. Although $\mathrm{Ta}^{5+}$ has a similar ionic radius to $\mathrm{Ti}^{4+}$, the electron density around $\mathrm{Ta}$ and the doping induced oxygen vacancies cause the rearrangement of the nearby atoms $[16,33]$, which limits crystal growth. 


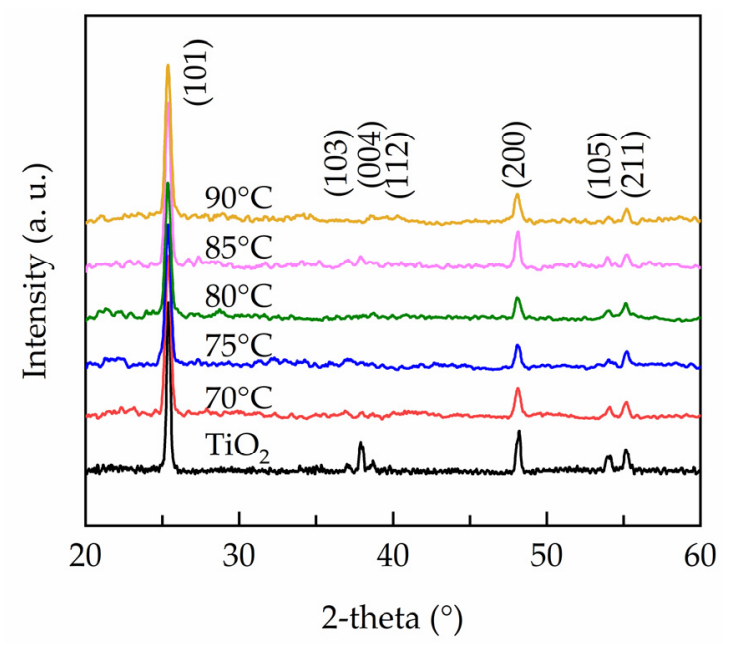

(a)

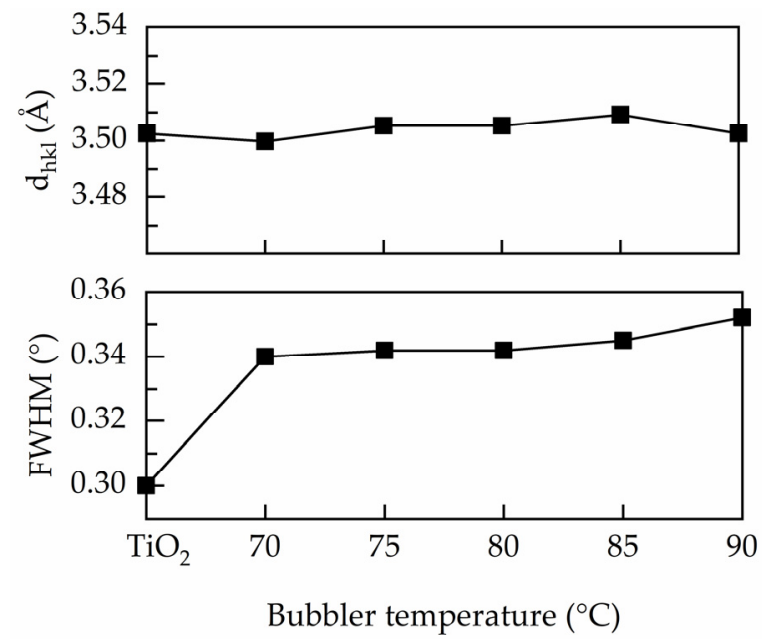

(b)

Figure 3. (a) XRD pattern, (b) interplanar distance and FWHM of the PEALD Ta-doped $\mathrm{TiO}_{2}$ films prepared at various bubbler temperatures.

Figure 4 shows the composition and chemical states measured by XPS for the PEALD Ta-doped $\mathrm{TiO}_{2}$ films prepared at different bubbler temperatures. Figure 4a shows the high-resolution Ta $4 \mathrm{f}$ for the PEALD films, evidencing the Ta incorporation into the $\mathrm{TiO}_{2}$ films. The Ta peaks can be deconvoluted into two Gaussian components at 21.7 and $23.7 \mathrm{eV}$, corresponding to $\mathrm{TaO}_{\mathrm{x}}(\mathrm{x}<2.5)$ [34].The atomic ratios of the $\mathrm{Ti}, \mathrm{O}$, and Ta elements are depicted in Figure $4 \mathrm{~b}$. The $\mathrm{TiO}_{2}$ film has an oxygen-deficient structure. The Ta content is varied from 0.82 to 0.95 at. $\%$ with increase in bubbler temperature from 70 to $90{ }^{\circ} \mathrm{C}$. The XPS spectra over the biding energy of 450 to $470 \mathrm{eV}$ corresponding to Ti $2 \mathrm{p}$ are shown in Figure $4 \mathrm{c}$. The binding energies of around $453-460 \mathrm{eV}$ and $460-466 \mathrm{eV}$ belong to Ti $2 \mathrm{p}_{3 / 2}$ and $\mathrm{Ti} 2 \mathrm{p}_{1 / 2}$, respectively [35]. Each spin state can further be deconvoluted into $\mathrm{Ti}^{4+}, \mathrm{Ti}^{3+}$ and $\mathrm{Ti}^{2+}$ peaks [36]. The Ti $2 \mathrm{p}_{3 / 2}$ peaks are analyzed, and the peak ratios of $\mathrm{Ti}^{2+}, \mathrm{Ti}^{3+}$ and $\mathrm{Ti}^{4+}$ to total are shown in Figure $4 \mathrm{~d}$. The $\mathrm{TiO}_{2}$ has the highest $\mathrm{T}^{\mathrm{i} 4+}$ peak ratio of about $60 \%$. At the bubbler temperature of $70{ }^{\circ} \mathrm{C}$, the $\mathrm{Ti}^{4+}$ ratio decreases and $\mathrm{Ti}^{3+}$ ratio increases, indicating that $\mathrm{Ta}$ dopants create oxygen vacancies and reduce $\mathrm{Ti}^{4+}$ to $\mathrm{Ti}^{3+}$. At the bubbler temperature of $90{ }^{\circ} \mathrm{C}$, the $\mathrm{Ti}^{4+}$ ratio further reduces and the $\mathrm{Ti}^{2+}$ ratio increases. This result suggests that the higher Ta incorporation causes $\mathrm{Ti}^{4+}$ to reduce to not only $\mathrm{Ti}^{3+}$ but also $\mathrm{Ti}^{2+}$. Figure 4e shows the high-resolution O 1s spectra for the PEALD films. The peaks are further split into two peaks, one at the lower binding energies (530-531 eV) assigned to lattice oxygen and the other at the higher binding energies of $531-532 \mathrm{eV}$ ascribed to oxygen ions in oxygen-deficient regions in the lattice [37]. The latter is usually deemed to reflect the presence of oxygen vacancies. The ratio of each component to total is calculated as shown in Figure $4 \mathrm{f}$. The lattice oxygen shows an opposite trend to defective oxygen. The increased defective oxygen ratio confirms that the Ta doping leads to the generation of oxygen vacancies defects. 


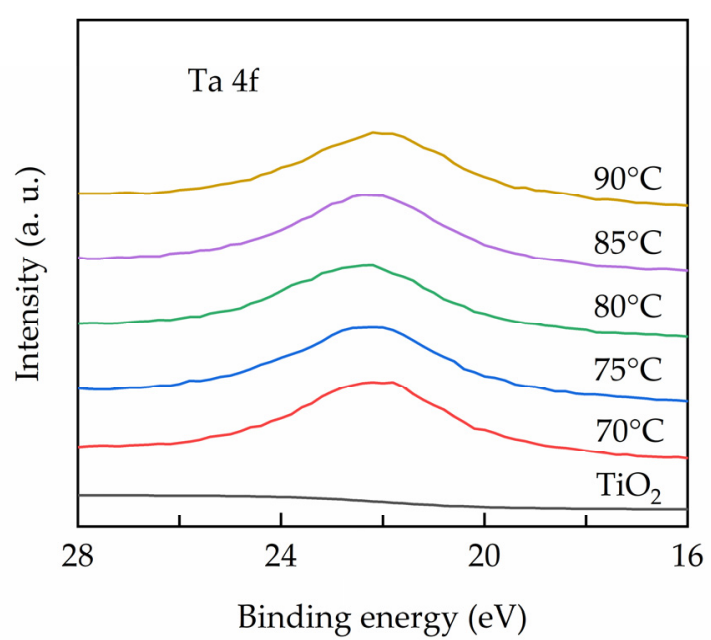

(a)

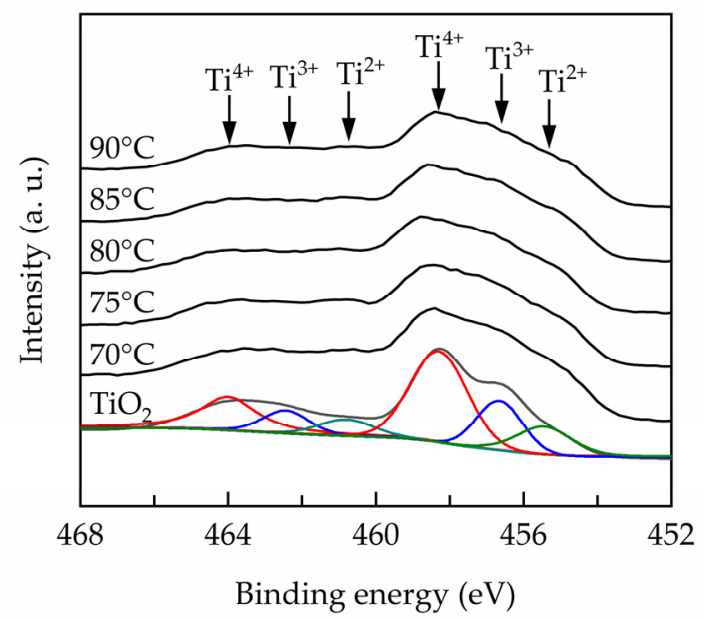

(c)

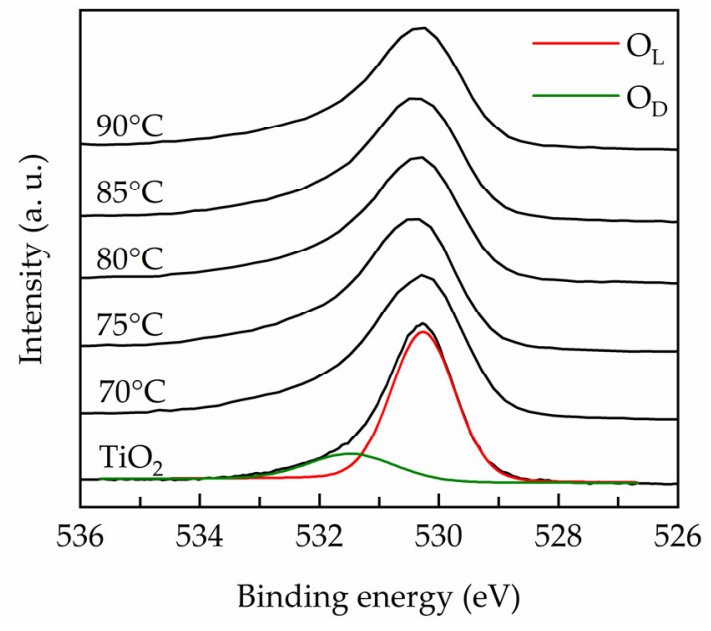

(e)

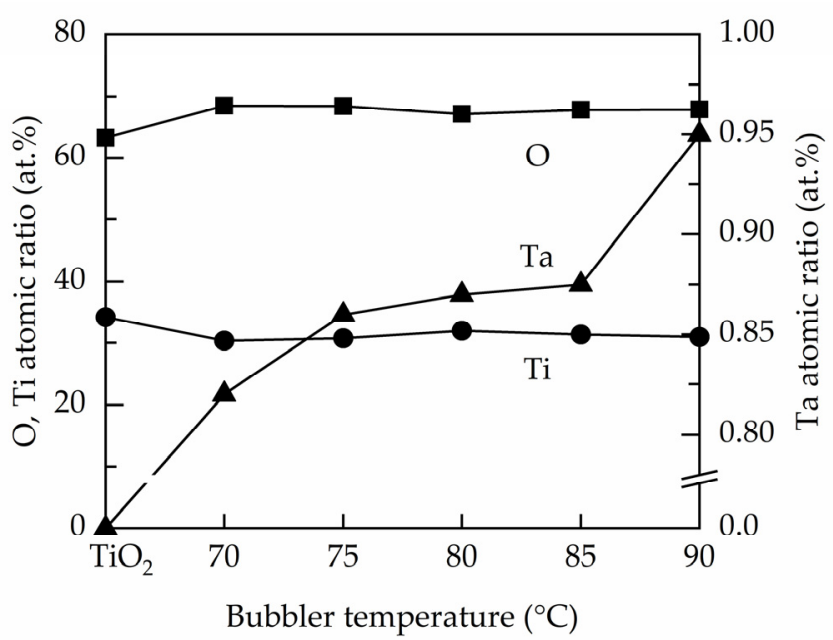

(b)

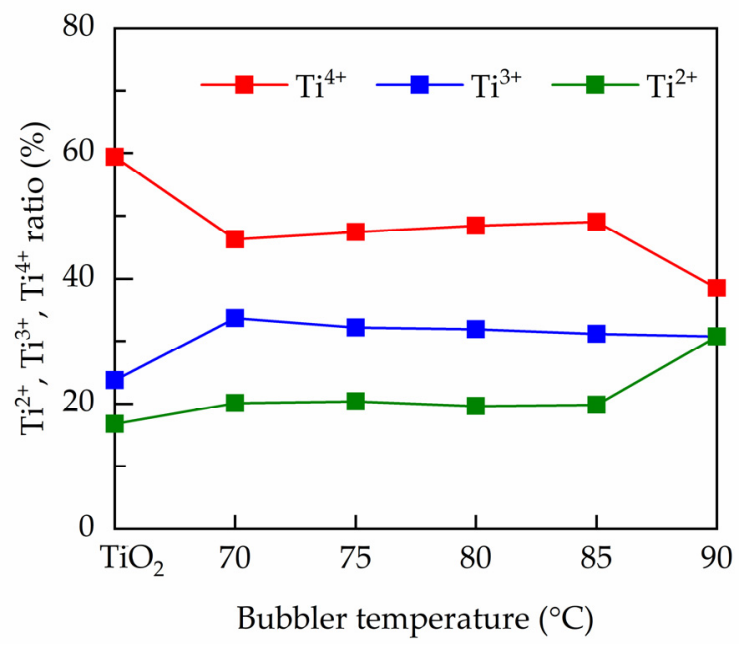

(d)

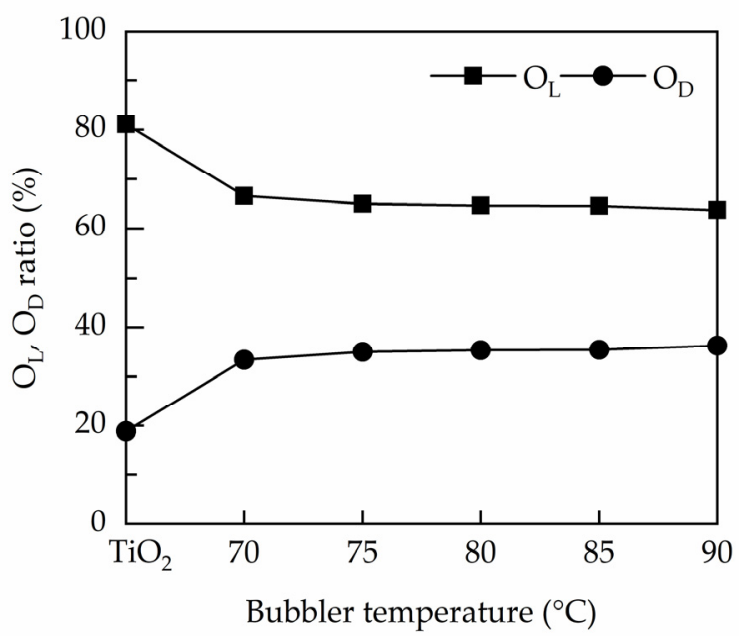

(f)

Figure 4. (a) Ta 4 f spectra, (b) $\mathrm{O}$, Ti and Ta atomic ratios, (c) $\mathrm{O} 1 \mathrm{~s}$ spectra, (d) $\mathrm{O}_{\mathrm{L}}$ and $\mathrm{O}_{\mathrm{D}}$ peak area ratios, (e) $\mathrm{Ti} 2 \mathrm{p}_{3 / 2}$ spectra, and $(\mathbf{f}) \mathrm{Ti}^{2+}, \mathrm{Ti}^{3+}$ and $\mathrm{Ti}^{4+}$ peak area ratios for the PEALD Ta-doped $\mathrm{TiO}_{2}$ films.

Figure 5 shows the UPS spectra for the PEALD Ta-doped $\mathrm{TiO}_{2}$ films prepared at different bubbler temperatures. As shown in Figure 5a, the extrapolation of the linear region of the curves to the binding energy axis gives the maximum valance band energy 
$\left(E_{V B M}\right)$ with respective to the Fermi energy. The curves in the high binding energy region are shown in Figure 5b, and similarly, the extrapolation of the linear region of the curves to the $\mathrm{x}$-axis corresponds to the cut-off energy $\left(\mathrm{E}_{\text {cutoff }}\right)$. Accordingly, the positions of Fermi level $\left(E_{F}\right)$ and valance band $\left(E_{V}\right)$ can be calculated as given by [38]:

$$
\begin{gathered}
\mathrm{E}_{\mathrm{F}}=\mathrm{E}_{\text {cutoff }}-21.2, \\
\mathrm{E}_{\mathrm{V}}=\mathrm{E}_{\mathrm{F}}-\mathrm{E}_{\mathrm{VBM}}
\end{gathered}
$$

where the value of $21.2 \mathrm{eV}$ corresponds to the energy of the used UV light source. The position of the conduction band $\left(\mathrm{E}_{\mathrm{c}}\right)$ is further obtained using: $\mathrm{E}_{\mathrm{C}}=\mathrm{E}_{\mathrm{v}}+\mathrm{E}_{\mathrm{g}}$ with the band gap values shown previously. The calculated $E_{c}$ and $E_{v}$ are summarized in Table 2. It is found the difference between the doped films is relatively small; however, the Ta-doped $\mathrm{TiO}_{2}$ films have both deeper conduction band and valence band edges, as compared to the undoped $\mathrm{TiO}_{2}$ film. The deep valance band positions favor the applications requiring hole blocking ability such as the electron transport layer in solar cells $[39,40]$. The lowered conduction band edges of the Ta-doped films indicate that Ta incorporation can adjust the conduction band position, which is benefit for interfacial band alignment engineering and a very important feature for being used as a selective charge transport layer of optoelectronics.

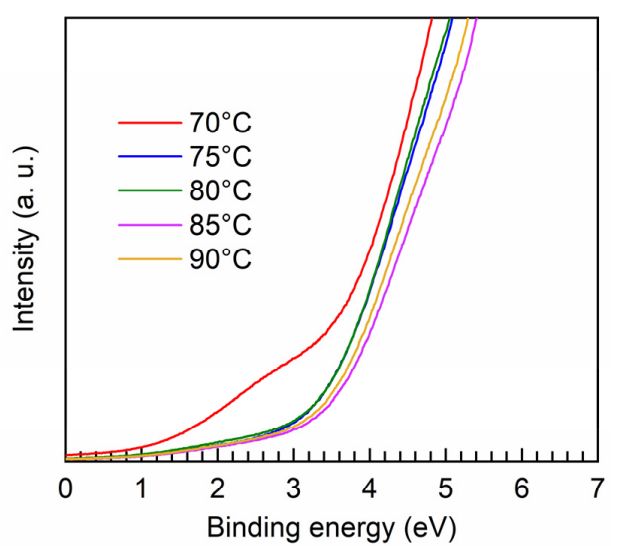

(a)

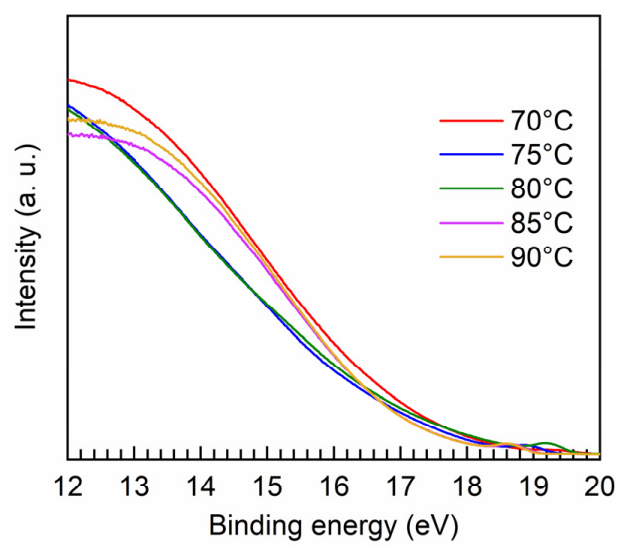

(b)

Figure 5. UPS spectra in the (a) low binding energy region and (b) high binding energy region for the PEALD Ta-doped $\mathrm{TiO}_{2}$ films prepared at different bubbler temperatures.

Table 2. Band gap, valance band position, and conduction band position for the PEALD Ta-doped $\mathrm{TiO}_{2}$ films with different bubbler temperatures.

\begin{tabular}{cccc}
\hline Bubbler Temperature $\left({ }^{\circ} \mathbf{C}\right)$ & Band Gap $(\mathbf{e V})$ & $\mathbf{E}_{\mathbf{v}}(\mathbf{e V})$ & $\mathbf{E}_{\mathbf{c}}(\mathbf{e V})$ \\
\hline $\mathrm{TiO}_{2}$ & 3.17 & -7.07 & -3.9 \\
70 & 3.09 & -7.19 & -4.1 \\
75 & 3.06 & -7.19 & -4.13 \\
80 & 3.05 & -7.22 & -4.17 \\
85 & 3.04 & -7.24 & -4.2 \\
90 & 3 & -7.24 & -4.23 \\
\hline
\end{tabular}

Figure 6 shows the resistivity measured by a four-point probe for the PEALD Ta-doped $\mathrm{TiO}_{2}$ films prepared at different bubbler temperatures. $\mathrm{The}^{\mathrm{TiO}}{ }_{2}$ exhibits a considerably high resistivity of $3.4 \times 10^{2} \Omega \cdot \mathrm{cm}$. The Ta incorporation leads to significant reduction in resistivity. All the Ta-doped $\mathrm{TiO}_{2}$ films have resistivities at the order of $10^{-1} \Omega \cdot \mathrm{cm}$. The minimum resistivity is $3 \times 10^{-1} \Omega \cdot \mathrm{cm}$ at the bubbler temperature of $90^{\circ} \mathrm{C}$. The decrease in resistivity is due to the Ta substitution for Ti atoms in the lattice sites, contributing free electrons. In addition, the Ta incorporation also results in creation of oxygen vacancies 
(as suggested by XPS), which are widely known as one of the sources of free electrons. Similar resistivity reduction due to the Ta doping is reported by other studies. For example, the resistivity of the Ta-doped $\mathrm{TiO}_{2}$ films prepared using metal organic chemical vapor deposition decreases four to six orders for at a high Ta doping level of 4-5\% [17,41]. In the present work, the Ta content for the bubbler temperatures of $70-90{ }^{\circ} \mathrm{C}$ is between 0.82 and 0.95 at.\%, leading to resistivities three orders lower than that of the undoped $\mathrm{TiO}_{2}$ film.

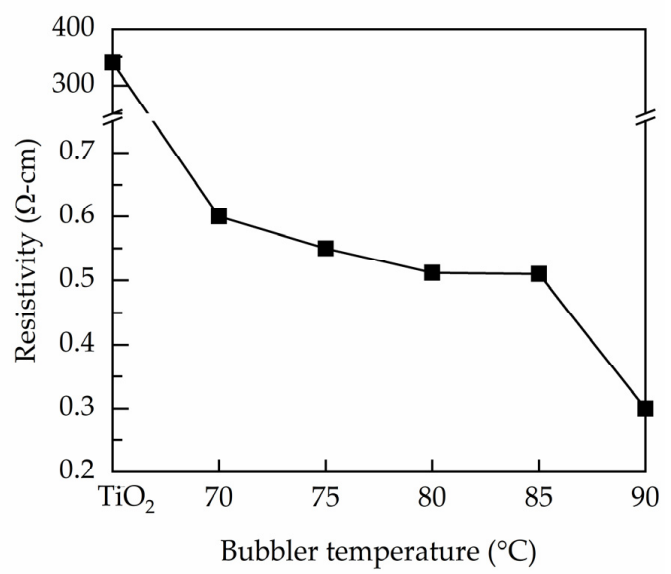

Figure 6. Four-point probe resistivity of the PEALD Ta-doped $\mathrm{TiO}_{2}$ films prepared at different bubbler temperature.

Figure 7 depicts the isolated energy band diagram of conventional $\mathrm{TiO}_{2}$ ETL-based PSCs. The $E_{c}$ and $E_{v}$ values of each layer are experimentally determined. Similar values can be found in other studies [42-45]. The photogenerated electrons and holes move towards different directions. A downward shift of CBM is generally favorable in the viewpoint of electron transport. However, as shown in the inset of Figure 7, the undoped $\mathrm{TiO}_{2}$ layer has a shallower CBM than the perovskite absorber, which causes the band mismatch and obstacles for electron transport. The charge accumulation at the perovskite $/ \mathrm{TiO}_{2}$ interface could resist electrons to flow into FTO. In the case of the adoption of Ta-doped $\mathrm{TiO}_{2}$, with the experimental $\mathrm{E}_{\mathrm{c}}$ values around -(4.1-4.23) eV shown in the UPS result, the band mismatch is supposed to be mitigated or absent due to the deeper conduction band edge. Considering the conduction band of the perovskite layer $(-4.21 \mathrm{eV})$, the Ta-doped $\mathrm{TiO}_{2}$ prepared at the bubbler temperature of $85^{\circ} \mathrm{C}$ is used for device fabrication due to the least conduction band offset.

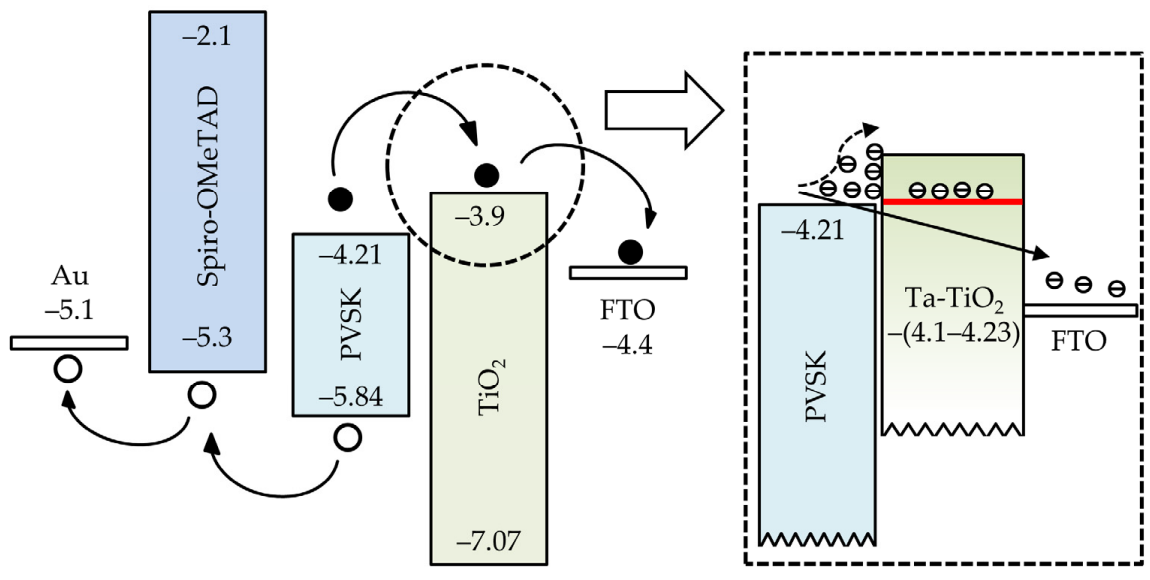

Figure 7. Isolated energy band diagram of each material involved in a $\mathrm{TiO}_{2}$ ETL-based PSC. The inset indicates the interfaces of perovskite $/ \mathrm{TiO}_{2}$ and perovskite/Ta-doped $\mathrm{TiO}_{2}$ ETL. 
Figure 8a shows the band-bending of energy levels in the PSCs with undoped $\mathrm{TiO}_{2}$ and Ta-doped $\mathrm{TiO}_{2}$ ETL deposited at the bubbler temperature of $85^{\circ} \mathrm{C}$. The major difference is at the ETL/perovskite interface. A conduction band barrier is clearly presented at the undoped $\mathrm{TiO}_{2}$ / perovskite absorber interface; however, the barrier disappears in the case of using Ta-doped $\mathrm{TiO}_{2}$ ETL due to the very little conduction band mismatch. This is expected to be reflected on the improvement in FF of the devices. In addition, as shown in the inset, the slope of the conduction band of the Ta-doped $\mathrm{TiO}_{2}$ device is steeper than that of undoped $\mathrm{TiO}_{2}$ device, and this implies a greater built-in electric field, which could enhance the separation of photo-generated electron-hole pairs. The J-V characteristics of the fabricated PSCs in the forward and reverse scans are shown in Figure 8b, and the corresponded external photovoltaic parameters are listed in Table 3. Apart from the slightly improved $\mathrm{V}_{\mathrm{oc}}$ and $\mathrm{J}_{\mathrm{sc}}$, the cell with the Ta-doped $\mathrm{TiO}_{2}$ ETL has a considerably enhanced FF. The SEM images of the PEALD $\mathrm{TiO}_{2}$ and Ta-doped $\mathrm{TiO}_{2}$ films are shown in Figure S1. The two samples are compact without observable pinholes, and do not show much difference in surface morphology likely due to the low-Ta doping level. It is believed that the FF improvement of the perovskite solar cells with the Ta-doped $\mathrm{TiO}_{2}$ ETL is due to the reduction of the conduction band mismatch, thereby decreasing the transport barrier of electrons. This demonstrates the significance of the conduction band alignment of the ETL. In addition to the absence of the transport barrier at perovskite/ETL interface, the improved FF of the device with the Ta-doped $\mathrm{TiO}_{2}$ ETL is partially owing to the smaller series resistance as assessed from the inverse slope of the $J-V$ curves at the $V_{\text {oc }}$-point. The hysteresis index of the PSCs is investigated, which is given as [46]:

$$
\text { Hysteresis }=\frac{\int_{\mathrm{OC}}^{\mathrm{SC}} \mathrm{J}_{\mathrm{R}}(\mathrm{V}) \varphi(\mathrm{V}) \mathrm{dV}-\int_{\mathrm{SC}}^{\mathrm{OC}} \mathrm{J}_{\mathrm{F}}(\mathrm{V}) \varphi(\mathrm{V}) \mathrm{dV}}{\int_{\mathrm{OC}}^{\mathrm{SC}} \mathrm{J}_{\mathrm{R}}(\mathrm{V}) \varphi(\mathrm{V}) \mathrm{dV}+\int_{\mathrm{SC}}^{\mathrm{OC}} \mathrm{J}_{\mathrm{F}}(\mathrm{V}) \varphi(\mathrm{V}) \mathrm{dV}},
$$

where the subscript $\mathrm{R}$ represents reverse scan, $\mathrm{F}$ denotes the forward scan, and $\mathrm{H}$ is the unit step function. The result reveals the hysteresis of $1.06 \%$ for the device with undoped $\mathrm{TiO}_{2}$ ETL and $0.21 \%$ for the cell with Ta-doped $\mathrm{TiO}_{2}$ ETL. This is in agreement with the findings reported by Kim et al. [47], where PSCs with doped metal oxide ETLs exhibit less hysteresis compared to undoped metal oxides. It is worth mentioning that the Ta-doped $\mathrm{TiO}_{2}$ film prepared at the bubbler temperature of $90^{\circ} \mathrm{C}$ has been also applied to PSC fabrication as it seems to have the lowest resistivity as well as an appropriate conduction band position. However, the resultant device conversion efficiency is lower than in the case of $85^{\circ} \mathrm{C}$ bubbler temperature. The J-V curve and the corresponded photovoltaic performance of the device at the bubbler temperature of $90{ }^{\circ} \mathrm{C}$ are shown in Figure S2. The device has conversion efficiency of $17.3 \%$ ( $\mathrm{V}_{\mathrm{oc}}$ of $1.1 \mathrm{~V}, \mathrm{~J}_{\mathrm{sc}}$ of $22.5 \mathrm{~mA} / \mathrm{cm}^{2}, \mathrm{FF}$ of 0.7$)$, lower than that $(18.09 \%)$ of the device with the Ta-doped $\mathrm{TiO}_{2}$ ETL deposited at $85^{\circ} \mathrm{C}$. It is speculated that the performance reduction might be related to the increased defect formation when the impurity doping level increases. This compromises the cell performance, and thus the optimal Ta bubbler temperature occurs at $85^{\circ} \mathrm{C}$.

Table 3. Performance of PSCs measured in the reverse and forward directions.

\begin{tabular}{ccccc}
\hline Parameter & $\mathbf{J}_{\mathbf{s c}}\left(\mathbf{m A} / \mathbf{c m}^{\mathbf{2}}\right)$ & $\mathbf{V}_{\mathbf{o c}} \mathbf{( V )}$ & $\mathbf{F F}$ & $\boldsymbol{\eta} \mathbf{( \% )}$ \\
\hline Undoped $\mathrm{TiO}_{2}$ (Forward) & 22.9 & 1.09 & 0.55 & 13.02 \\
Undoped $\mathrm{TiO}_{2}$ (Reverse) & 22.3 & 1.10 & 0.54 & 13.42 \\
Ta-doped $\mathrm{TiO}_{2}$ (Forward) & 22.8 & 1.11 & 0.70 & 17.91 \\
Ta-doped $\mathrm{TiO}_{2}$ (Reverse) & 23.0 & 1.11 & 0.71 & 18.09 \\
\hline
\end{tabular}




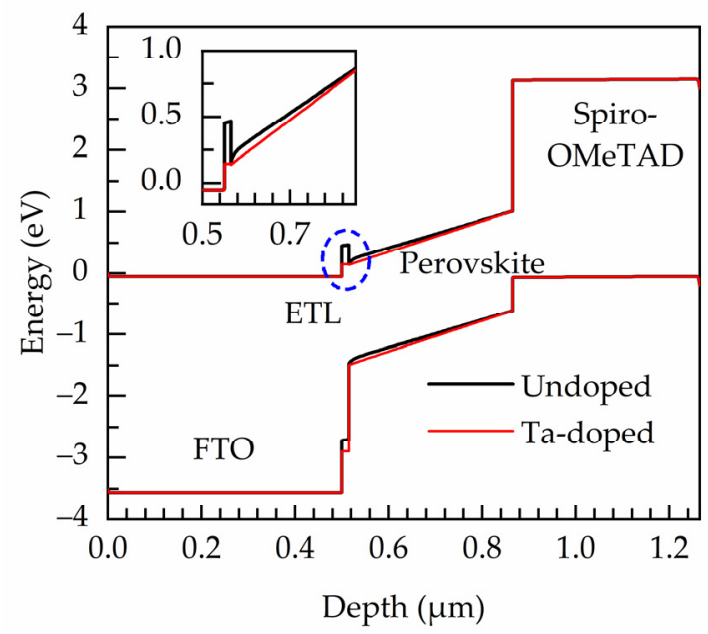

(a)

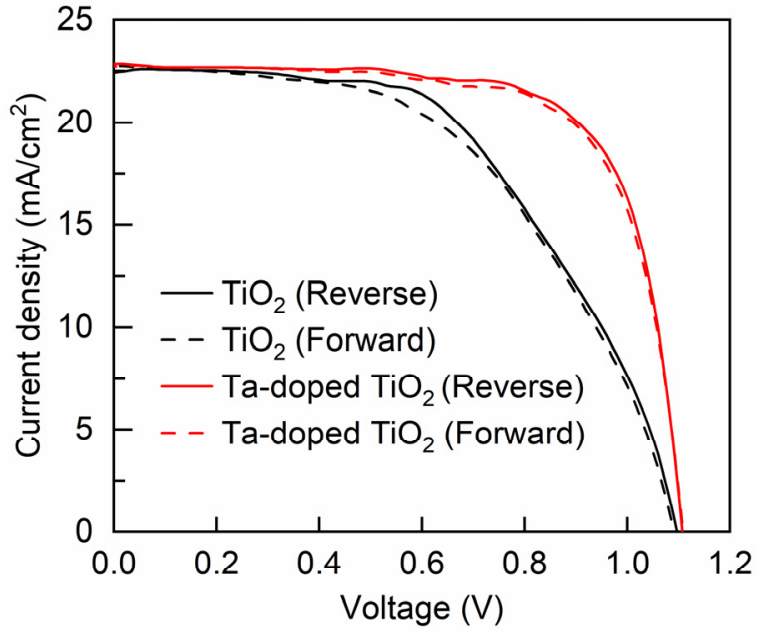

(b)

Figure 8. (a) Band bending of energy levels in PSCs. (b) J-V curves of the PSCs measured in reverse and forward directions. The inset shows the enlarged view at the ETL/perovskite interface.

The performance of 12 devices under reverse scan is shown in Figure 9 for $\mathrm{TiO}_{2}$ and Ta-doped $\mathrm{TiO}_{2}$ perovskite solar cells. The results demonstrate small standard deviations of the device photovoltaic parameters. For instance, the standard deviation of the device efficiency is less than $0.4 \%$ for $\mathrm{TiO}_{2}$ devices and $0.46 \%$ for $\mathrm{Ta}$-doped $\mathrm{TiO}_{2}$ devices, indicating high reproducibility. Moreover, the average conversion efficiency has the same trend shown in Figure 9, inferring that the comparison of efficiency among different groups is reliable.

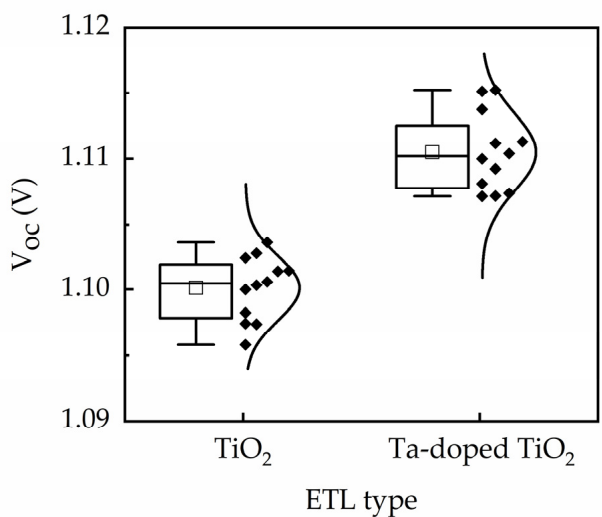

(a)

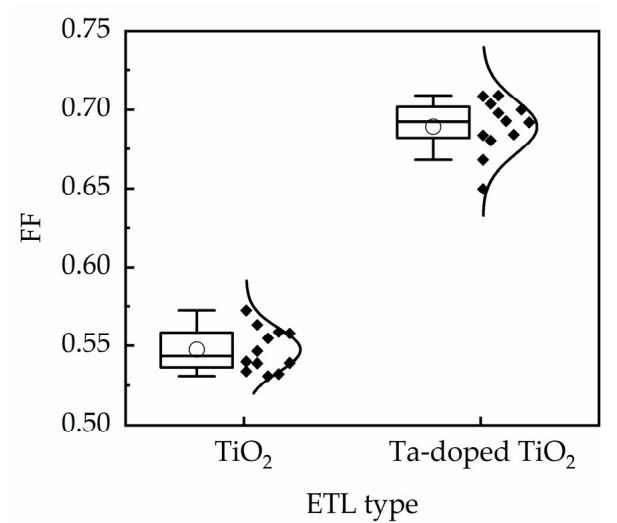

(c)

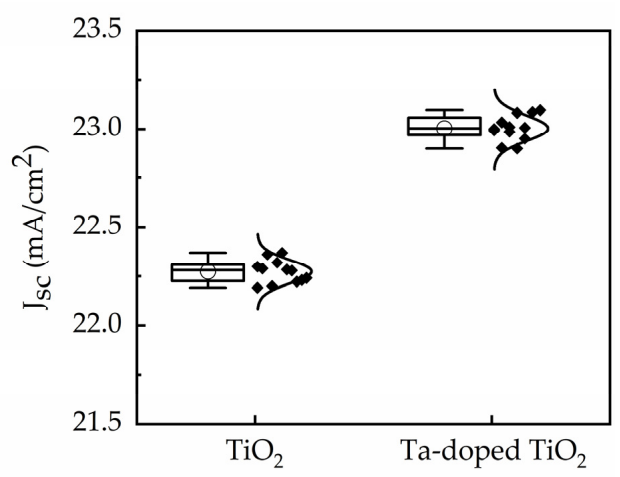

(b)

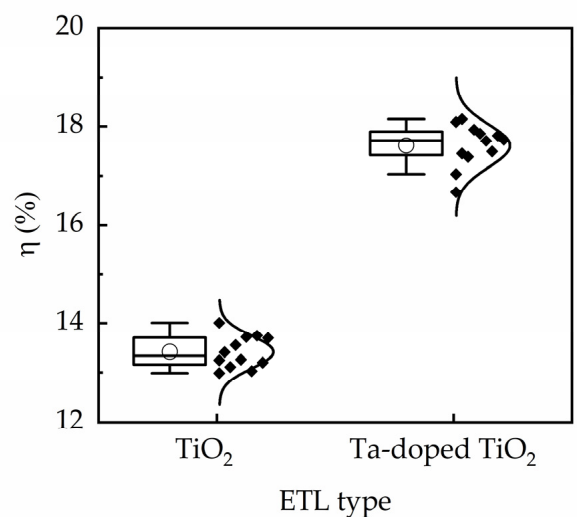

(d)

Figure 9. Performance of 12 devices for $\mathrm{TiO}_{2}$ and Ta-doped $\mathrm{TiO}_{2}$ perovskite solar cells: $(\mathbf{a}) \mathrm{V}_{\mathrm{oc}},(\mathbf{b}) \mathrm{J}_{\mathrm{sc}}$, (c) FF, and (d) $\eta$. 


\section{Conclusions}

The Ta-doped $\mathrm{TiO}_{2}$ thin films are prepared using PEALD with co-injected $\mathrm{Ta}(\mathrm{OEt})_{5}$ and TTIP metal precursors as Ta and Ti sources, respectively. The bubbler temperature varies to obtain different Ta content in the films. The XRD result shows that the Ta incorporation does not lead to additional crystalline phases but reduces crystallinity. As confirmed by XPS, the Ta dopants cause $\mathrm{Ti}^{4+}$ ions reducing to $\mathrm{Ti}^{3+}$ and $\mathrm{Ti}^{2+}$, due to the creation of the oxygen vacancies defects. The resistivity significantly reduces by three orders at the Ta content of $0.82-0.95$ at. $\%$, as compared to that of the undoped $\mathrm{TiO}_{2}$. The band gap, conduction band, and valence band position can be tailored by the Ta incorporation, and this is favorable for the applications involving interfacial band structure engineering. Finally, the PSC with Ta-doped $\mathrm{TiO}_{2}$ ETL demonstrates a significantly improved FF from 0.54 to 0.71 and conversion efficiency from $13.42 \%$ to $18.09 \%$ as compared to the PSC with conventionally undoped $\mathrm{TiO}_{2}$ ETL.

Supplementary Materials: The following are available online at https:/ /www.mdpi.com/article/10 .3390/nano11061504/s1, Figure S1: SEM images of PEALD (a) $\mathrm{TiO}_{2}$ and (b) Ta-doped $\mathrm{TiO}_{2}$ deposited at the bubbler temperature of $85^{\circ} \mathrm{C}$, Figure S2: J-V curve of the perovskite solar cell with the Ta-doped $\mathrm{TiO}_{2}$ ETL deposited at the bubbler temperature of $90^{\circ} \mathrm{C}$.

Author Contributions: Conceptualization, C.-H.H. and S.-Y.L.; methodology, K.-T.C.; formal analysis, C.-H.H., K.-T.C., L.-Y.L., W.-Y.W., L.-S.L., P.G., Y.Q. and W.-Z.Z.; investigation, K.-T.C., X.-Y.Z. and P.-H.H.; writing—original draft preparation, C.-H.H.; writing—review and editing, C.-H.H. and S.-Y.L.; supervision, S.-Y.L.; funding acquisition, C.-H.H., S.-Y.L. and P.G. All authors have read and agreed to the published version of the manuscript.

Funding: This work is supported by a scientific and technological project in Xiamen (no. 3502ZCQ20191002), scientific research projects of Xiamen University of Technology (no. 405011904, 40199029, YKJ19001R, and XPDKQ19006), the Natural Science Foundation of Fujian Province (no. 2020H0025, 2019J01877, 2020J01930). P.G. knowledge 'the National Natural Science Foundation of China (Grant No. 21975260), and the Recruitment Program of Global Experts (1000 Talents Plan) of China'. This study is also sponsored by the Fujian Association for Science and Technology.

Data Availability Statement: Data sharing is not applicable to this article as no new data were created or analyzed in this study.

Conflicts of Interest: The authors declare no conflict of interest.

\section{References}

1. Liu, Q.; Wang, J. Dye-sensitized solar cells based on surficial $\mathrm{TiO}_{2}$ modification. Sol. Energy 2019, 184, 454-465. [CrossRef]

2. Guo, Q.; Zhou, C.; Ma, Z.; Yang, X. Fundamentals of $\mathrm{TiO}_{2}$ photocatalysis: Concepts, mechanisms, and challenges. Adv. Mater. 2019, 31, 1901997. [CrossRef] [PubMed]

3. Wang, S.; Liu, B.; Zhu, Y.; Ma, Z.; Liu, B.; Miao, X.; Ma, R.; Wang, C. Enhanced performance of $\mathrm{TiO}_{2}$-based perovskite solar cells with ru-doped TiO2 electron transport layer. Sol. Energy 2018, 169, 335-342. [CrossRef]

4. Wu, M.-C.; Chan, S.-H.; Lee, K.-M.; Chen, S.-H.; Jao, M.-H.; Chen, Y.-F.; Su, W.-F. Enhancing the efficiency of perovskite solar cells using mesoscopic zinc-doped $\mathrm{TiO}_{2}$ as the electron extraction layer through band alignment. J. Mater. Chem. A 2018, 6, 16920-16931. [CrossRef]

5. Khlyustova, A.; Sirotkin, N.; Kusova, T.; Kraev, A.; Titov, V.; Agafonov, A. Doped $\mathrm{TiO}_{2}$ : The effect of doping elements on photocatalytic activity. Mater. Adv. 2020, 1, 1193-1201. [CrossRef]

6. El Ruby Mohamed, A.; Rohani, S. Modified $\mathrm{TiO}_{2}$ nanotube arrays (TNTAs): Progressive Strategies towards visible light responsive photoanode, a review. Energy Environ. Sci. 2011, 4, 1065. [CrossRef]

7. Singh, S.; Srivastava, P.; Bahadur, L. Neetu Hydrothermal synthesized Nd-doped $\mathrm{TiO}_{2}$ with anatase and brookite phases as highly improved photoanode for dye-sensitized solar cell. Sol. Energy 2020, 208, 173-181. [CrossRef]

8. Sun, J.; Yu, S.; Zheng, Q.; Cheng, S.; Wang, X.; Zhou, H.; Lai, Y.; Yu, J. Improved performance of inverted organic solar cells by using la-doped $\mathrm{TiO}_{2}$ film as electron transport layer. J. Mater Sci. Mater Electron. 2017, 28, 2272-2278. [CrossRef]

9. Qu, X.; Hou, Y.; Liu, M.; Shi, L.; Zhang, M.; Song, H.; Du, F. Yttrium doped $\mathrm{TiO}_{2}$ porous film photoanode for dye-sensitized solar cells with enhanced photovoltaic performance. Results Phys. 2016, 6, 1051-1058. [CrossRef]

10. Akpan, U.G.; Hameed, B.H. The advancements in sol-gel method of doped- $\mathrm{TiO}_{2}$ photocatalysts. Appl. Catal. A Gen. 2010, 375, 1-11. [CrossRef] 
11. Cui, Q.; Zhao, X.; Lin, H.; Yang, L.; Chen, H.; Zhang, Y.; Li, X. Improved efficient perovskite solar cells based on ta-doped TiO 2 nanorod arrays. Nanoscale 2017, 9, 18897-18907. [CrossRef] [PubMed]

12. Carey, J.J.; McKenna, K.P. Screening doping strategies to mitigate electron trapping at anatase $\mathrm{TiO}_{2}$ surfaces. J. Phys. Chem. C 2019, 123, 22358-22367. [CrossRef]

13. Ranjan, R.; Prakash, A.; Singh, A.; Singh, A.; Garg, A.; Gupta, R.K. Effect of tantalum doping in a $\mathrm{TiO}_{2}$ compact layer on the performance of planar Spiro-OMeTAD free perovskite solar cells. J. Mater. Chem. A 2018, 6, 1037-1047. [CrossRef]

14. Xu, C.; Lin, D.; Niu, J.-N.; Qiang, Y.-H.; Li, D.-W.; Tao, C.-X. Preparation of Ta-Doped $\mathrm{TiO}_{2} \mathrm{Using} \mathrm{Ta}_{2} \mathrm{O}_{5}$ as the doping source. Chin. Phys. Lett. 2015, 32, 088102. [CrossRef]

15. Alim, M.A. Photocatalytic Properties of Ta-Doped $\mathrm{TiO}_{2}$. Ionics 2017, 23, 1-15. [CrossRef]

16. Pan, X.; Yang, M.-Q.; Fu, X.; Zhang, N.; Xu, Y.-J. Defective $\mathrm{TiO}_{2}$ with oxygen vacancies: Synthesis, properties and photocatalytic applications. Nanoscale 2013, 5, 3601. [CrossRef]

17. Zhao, W.; He, L.; Feng, X.; Luan, C.; Ma, J. Structural, electrical and optical properties of epitaxial ta-doped titania films by MOCVD. Cryst. Eng. Comm. 2018, 20, 5395-5401. [CrossRef]

18. Choi, J.-H.; Kwon, S.-H.; Jeong, Y.-K.; Kim, I.; Kim, K.-H. Atomic layer deposition of Ta-doped TiO 2 electrodes for dye-sensitized solar cells. J. Electrochem. Soc. 2011, 158, B749. [CrossRef]

19. Hitosugi, T.; Furubayashi, Y.; Ueda, A.; Itabashi, K.; Inaba, K.; Hirose, Y.; Kinoda, G.; Yamamoto, Y.; Shimada, T.; Hasegawa, T. Ta-doped anatase $\mathrm{TiO}_{2}$ epitaxial film as transparent conducting oxide. Jpn. J. Appl. Phys. 2005, 44, L1063-L1065. [CrossRef]

20. Bawaked, S.M.; Sathasivam, S.; Bhachu, D.S.; Chadwick, N.; Obaid, A.Y.; Al-Thabaiti, S.; Basahel, S.N.; Carmalt, C.J.; Parkin, I.P. Aerosol assisted chemical vapor deposition of conductive and photocatalytically active tantalum doped titanium dioxide films. $J$. Mater. Chem. A 2014, 2, 12849. [CrossRef]

21. Dasgupta, N.P.; Lee, H.-B.-R.; Bent, S.F.; Weiss, P.S. Recent advances in atomic layer deposition. Chem. Mater. 2016, 28 , 1943-1947. [CrossRef]

22. Hajibabaei, H.; Zandi, O.; Hamann, T.W. Tantalum nitride films integrated with transparent conductive oxide substrates via atomic layer deposition for photoelectrochemical water splitting. Chem. Sci. 2016, 7, 6760-6767. [CrossRef] [PubMed]

23. Jeong, S.; Seo, S.; Park, H.; Shin, H. Atomic layer deposition of a $\mathrm{SnO}_{2}$ electron-transporting layer for planar perovskite solar cells with a power conversion efficiency of 18.3\%. Chem. Commun. 2019, 55, 2433-2436. [CrossRef] [PubMed]

24. Niu, G.; Li, W.; Li, J.; Liang, X.; Wang, L. Enhancement of thermal stability for perovskite solar cells through cesium doping. RSC Adv. 2017, 7, 17473-17479. [CrossRef]

25. Pfeiffer, K.; Schulz, U.; Tünnermann, A.; Szeghalmi, A. Antireflection coatings for strongly curved glass lenses by atomic layer deposition. Coatings 2017, 7, 118. [CrossRef]

26. Zhao, C.; Hedhili, M.N.; Li, J.; Wang, Q.; Yang, Y.; Chen, L.; Li, L. Growth and characterization of titanium oxide by plasma enhanced atomic layer deposition. Thin Solid Films 2013, 542, 38-44. [CrossRef]

27. Heil, S.B.S.; Roozeboom, F.; van de Sanden, M.C.M.; Kessels, W.M.M. Plasma-assisted atomic layer deposition of $\mathrm{Ta}_{2} \mathrm{O}_{5} \mathrm{from}$ alkylamide precursor and remote $\mathrm{O}_{2}$ plasma. J. Vac. Sci. Technol. A Vac. Surf. Film. 2008, 26, 472-480. [CrossRef]

28. Maeng, W.J.; Park, S.-J.; Kim, H. Atomic layer deposition of Ta-Based thin films: Reactions of alkylamide precursor with various reactants. J. Vac. Sci. Technol. B 2006, 24, 2276. [CrossRef]

29. Chen, H.; Gu, H.; Xing, J.; Wang, Z.; Zhou, G.; Wang, S. Correlated evolution of dual-phase microstructures, mutual solubilities and oxygen vacancies in transparent $\mathrm{La}_{2}-\mathrm{Lu} \mathrm{Zr}_{2} \mathrm{O}_{7}$ ceramics. J. Mater. 2021, 7, 185-194. [CrossRef]

30. Tauc, J. Optical properties and electronic structure of amorphous Ge and Si. Mater. Res. Bull. 1968, 3, 37-46. [CrossRef]

31. Deák, P.; Aradi, B.; Frauenheim, T. Band lineup and charge carrier separation in mixed rutile-anatase systems. J. Phys. Chem. C 2011, 115, 3443-3446. [CrossRef]

32. Wang, J.; Wang, Z.; Huang, B.; Ma, Y.; Liu, Y.; Qin, X.; Zhang, X.; Dai, Y. Oxygen vacancy induced band-gap narrowing and enhanced visible light photocatalytic activity of ZnO. ACS Appl. Mater. Interfaces 2012, 4, 4024-4030. [CrossRef] [PubMed]

33. Liu, Y.; Zhou, W.; Wu, P. Electronic Structure and optical properties of Ta-doped and (Ta, N)-codoped $\mathrm{SrTiO}_{3}$ from hybrid functional calculations. J. Appl. Phys. 2017, 121, 075102. [CrossRef]

34. Rahaman, S.; Maikap, S.; Tien, T.-C.; Lee, H.-Y.; Chen, W.-S.; Chen, F.T.; Kao, M.-J.; Tsai, M.-J. Excellent resistive memory characteristics and switching mechanism using a Ti nanolayer at the $\mathrm{Cu} / \mathrm{TaO}_{\mathrm{x}}$ interface. Nanoscale Res. Lett. 2012, 7, 345. [CrossRef] [PubMed]

35. Vikraman, D.; Park, H.J.; Kim, S.-I.; Thaiyan, M. Magnetic, structural and optical behavior of cupric oxide layers for solar cells. J. Alloy. Compd. 2016, 686, 616-627. [CrossRef]

36. Kruse, N.; Chenakin, S. XPS Characterization of $\mathrm{Au} / \mathrm{TiO}_{2}$ catalysts: Binding energy assessment and irradiation effects. Appl. Catal. A Gen. 2011, 391, 367-376. [CrossRef]

37. Hannula, M.; Ali-Löytty, H.; Lahtonen, K.; Sarlin, E.; Saari, J.; Valden, M. Improved stability of atomic layer deposited amorphous $\mathrm{TiO}_{2}$ photoelectrode coatings by thermally induced oxygen defects. Chem. Mater. 2018, 30, 1199-1208. [CrossRef] [PubMed]

38. Wang, J.; Qin, M.; Tao, H.; Ke, W.; Chen, Z.; Wan, J.; Qin, P.; Xiong, L.; Lei, H.; Yu, H.; et al. Performance enhancement of perovskite solar cells with $\mathrm{Mg}$-doped $\mathrm{TiO}_{2}$ compact film as the hole-blocking layer. Appl. Phys. Lett. 2015, 106, 121104. [CrossRef]

39. Zhu, L.; Lu, Q.; Lv, L.; Wang, Y.; Hu, Y.; Deng, Z.; Lou, Z.; Hou, Y.; Teng, F. Ligand-free rutile and anatase $\mathrm{TiO}_{2}$ nanocrystals as electron extraction layers for high performance inverted polymer solar cells. RSC Adv. 2017, 7, 20084-20092. [CrossRef] 
40. Man, G.; Schwartz, J.; Sturm, J.C.; Kahn, A. Electronically passivated hole-blocking titanium dioxide/silicon heterojunction for hybrid silicon photovoltaics. Adv. Mater. Interfaces 2016, 3, 1600026. [CrossRef]

41. Mazzolini, P.; Gondoni, P.; Russo, V.; Chrastina, D.; Casari, C.S.; Li Bassi, A. Tuning of electrical and optical properties of highly conducting and transparent Ta-doped $\mathrm{TiO}_{2}$ polycrystalline films. J. Phys. Chem. C 2015, 119, 6988-6997. [CrossRef]

42. Lin, L.; Jiang, L.; Li, P.; Li, X.; Qiu, Y. Numerical modeling of inverted perovskite solar cell based on CZTSSe hole transport layer for efficiency improvement. J. Photon. Energy 2019, 9, 1. [CrossRef]

43. Anwar, F.; Mahbub, R.; Satter, S.S.; Ullah, S.M. Effect of different HTM layers and electrical parameters on ZnO nanorod-based lead-free perovskite solar cell for high-efficiency performance. Int. J. Photoenergy 2017, 2017, 9846310. [CrossRef]

44. Lin, L.; Jiang, L.; Li, P.; Xiong, H.; Kang, Z.; Fan, B.; Qiu, Y. Simulated development and optimized performance of CsPbI 3 based all-inorganic perovskite solar cells. Sol. Energy 2020, 198, 454-460. [CrossRef]

45. Liang, L.; Luo, H.; Hu, J.; Li, H.; Gao, P. Efficient perovskite solar cells by reducing interface-mediated recombination: A bulky amine approach. Adv. Energy Mater. 2020, 10, 2000197. [CrossRef]

46. Lee, J.-W.; Kim, S.-G.; Bae, S.-H.; Lee, D.-K.; Lin, O.; Yang, Y.; Park, N.-G. The interplay between trap density and hysteresis in planar heterojunction perovskite solar cells. Nano Lett. 2017, 17, 4270-4276. [CrossRef]

47. Kim, J.K.; Chai, S.U.; Ji, Y.; Levy-Wendt, B.; Kim, S.H.; Yi, Y.; Heinz, T.F.; Nørskov, J.K.; Park, J.H.; Zheng, X. Resolving hysteresis in perovskite solar cells with rapid flame-processed cobalt-doped $\mathrm{TiO}_{2}$. Adv. Energy Mater. 2018, 8, 1801717. [CrossRef] 